\title{
PRAKSIS PEMBELAJARAN KEWIRAUSAHAAN PADA UNIT PRODUKSI JASA BOGA
}

\author{
Tuatul Mahfud \\ Sekolah Indonesia di Sabah Malaysia \\ mahfud_unj@yahoo.co.id \\ Pardjono \\ Jurusan Pendidikan Teknik Mesin \\ jpardjono@yahoo.com
}

\begin{abstract}
Abstrak: Praksis pembelajaran kewirausahaan pada unit produksi jasa boga. Penelitian bertujuan menemukan konsepsi guru tentang pembelajaran kewirausahaan, kompetensi kewirausahaan yang dikembangkan pada unit produksi sekolah dalam bidang jasa boga. Penelitian ini menggunakan metode kualitatif jenis studi kasus. Subjek penelitian adalah kepala sekolah, ketua program studi, kepala unit produksi, dan siswa. Data dikumpulkan melalui wawancara, observasi, dan dokumentasi dan dianalisis menggunakan model interaktif dari Miles dan Huberman yang terdiri dari reduksi data, data display, dan kesimpulan. Hasil penelitian menunjukkan bahwa: (1) belajar kewirausahaan memerlukan kegiatan nyata (hands-on) dengan melibatkan siswa pada kegiatan usaha yang nyata dalam unit produksi; (2) kompetensi kewirausahaan dikembangkan melalui unit produksi adalah: pengetahuan tentang kewirausahaan melalui pengetahuan diri dan pengetahuan praktis; sikap kewirausahaan meliputi etos kerja, disiplin, kemandirian, dan kreativitas, keterampilan berkomunikasi, keterampilan konseptual, keterampilan pengambilan keputusan, keterampilan mengatur waktu, keterampilan kepemimpinan. Model pembelajaran kewirausahaan yang dikembangkan melalui unit produksi adalah: produksi luar dan produksi dalam, dan kantin mobil. Evaluasi dan monitoring dilakukan melalui dua cara, dengan monitoring kinerja dan produk.
\end{abstract}

Kata Kunci: pembelajaran, entrepreneurship, unit produksi

\begin{abstract}
The Praxis of Entrepreneurship Learning in the Food services Production Unit. This study aims to investigate teachers' concepts of entrepreneurship learning, entrepreneurship competencies developed in the production unit, and entrepreneurship learning processes in the production unit of food services in SMK Negeri 6 Yogyakarta. This study employed the qualitative case study. The research subjects were the principal, head of the study program, head of the production unit, and students. Data were collected through interviews, observations, and documentation. The collected data were analyzed using Miles and Huberman model consisting of data reduction, data display, and conclusion. The result shows that: (1) Entrepreneurship learning needs hands-on-experiences-based; (2) the entrepreneurship competency developed through the production unit includes a) entrepreneurship knowledge, consisting of self-knowledge and practical knowledge, b) entrepreneurship attitudes, consisting of work ethos, autonomy, discipline, creativity, and innovativeness, and c) entrepreneurship skills, consisting of: technical skill, human relations skill, conceptual skill, decision making skill, time management skill, and leadership skill; (3) no instructional standard employed in to develop entrepreneurship in production unit. There are three entrepreneurship learning models employed in the production unit: inside production, outside production, and mobile canteen. The learning outcome is measured in two ways, i.e. performance and product monitoring. Meanwhile, evaluation of the students' learning progress is conducted by using profit-based evaluation.
\end{abstract}

Keywords: learning, entrepreneurship, production unit 


\section{PENDAHULUAN}

Dalam era global, dunia pendidikan di Indonesia pada saat ini dan yang akan datang masih menghadapi tantangan yang semakin berat serta kompleks. Indonesia harus mampu bersaing dengan negara-negara lain baik dalam produk, pelayanan, maupun dalam penyiapan sumber daya manusia (SDM). Salah satu contoh perlunya pengembangan potensi SDM yang berkualitas ditunjukan dengan hasil survei yang dilakukan oleh UNDP mengenai Human Devopment Indeks (HDI) pada tahun 2007 menyebutkan bahwa posisi Indonesia dalam peringkat daya saing bangsa di dunia internasional adalah nomor 111 dengan skor 0.734 dari 182 negara Asia Afrika yang disurvei HDI (UNDP, 2007: 168).

Untuk memperoleh SDM yang berkualitas dan memiliki daya saing, perlu didukung oleh suatu sistem pendidikan dan pelatihan nasional yang dikembangkan berdasar pada kebutuhan pasar kerja dan dinamika percepatan perubahan yang terjadi pada dunia usaha dan dunia industri. Dalam konteks perkembangan dan perubahan yang terjadi dalam masyarakat Indonesia dewasa ini, daya saing bangsa tergantung pada pengetahuan dan keterampilan tenaga kerjanya dan untuk membuat tenaga kerja berpengetahuan dan berketerampilan tergantung pada kualitas pendidikan dan pelatihan, terutama pendidikan kejuruan. Tenaga kerja yang terlatih dan terampil tentu akan dapat meningkatkan nilai tambah produk yang dihasilkan melalui ciri-ciri peningkatan produktivitas, pengurangan biaya produksi, hasil yang diperoleh berkualitas tinggi, dan investasi dapat kembali dalam waktu yang relatif lebih cepat (rate of return). Disamping itu lembaga pendidikan kejuruan dituntut untuk menunjukkan peran dan kemampuannya sebagai institusi yang mampu "memasok" sumber daya manusia untuk kebutuhan masyarakat.

Sejalan dengan kondisi tersebut, maka dalam hal ini SMK harus semakin siap membekali tamatannya dengan kompetensi yang dibutuhkan oleh dunia kerja sehingga tamatannya benar-benar mampu bersaing dan siap memenangkannya. Paradigma peran pendidikan kejuruan yang dimainkan lembaga pendidikan SMK ini diamanatkan oleh UndangUndang Sistem Pendidikan Nasional yang menekankan bahwa lulusan SMK diarahkan pada tiga pilar utama yaitu: (1) bekerja di dunia usaha dan dunia industri (DUDI), (2) bekerja secara mandiri atau usaha sendiri dan (3) melanjutkan studi ke jenjang perguruan tinggi terutama perguruan tinggi profesi/vokasi.

Disamping itu, dalam konteks sistem pendidikan di Indonesia sebagaimana disebutkan dalam Undang-undang Sistem Pendidikan Nasional Nomor 2 Tahun 1989 pasal 11 ayat 3 menyatakan bahwa pendidikan kejuruan adalah merupakan pendidikan yang mempersiapkan peserta didik untuk dapat bekerja pada bidang tertentu. Hal yang sama disebutkan dalam pasal 1 Peraturan Pemerintah Nomor 29 Tahun 1990 bahwa yang dimaksud dengan pendidikan menengah kejuruan ialah pendidikan pada jenjang pendidikan menengah yang mengutamakan pengembangan kemampuan peserta didik untuk melaksanakan jenis pekerjaan tertentu. Selanjutnya dalam Peraturan Pemerintah Nomor 29 Tahun 1990 Pasal 3, ayat 2, antara lain dinyatakan bahwa Pendidikan Menengah Kejuruan mengutamakan penyiapan 
siswa untuk memasuki lapangan kerja serta mengembangkan sikap professional.

Mengacu kepada Undang-Undang dan Peraturan Pemerintah di atas, maka akar pendidikan menengah kejuruan sesungguhnya adalah tersedianya lapangan kerja bagi tamatannya. Untuk mencapai tujuan tersebut, maka pendidikan menengah kejuruan tidak dapat dipisahkan dari Dunia Usaha/Dunia Industri/Dunia Kerja sebagai institusi penyerap tenaga kerja. Oleh karena itu pendidikan menengah kejuruan hendaknya dirancang, dilaksanakan, dan dievaluasi secara terkait (link) dengan Lapangan kerja (DU/DI). sehingga hasilnya benar-benar sesuai, cocok atau sepadan (match) dengan tuntutan dan kebutuhan Dunia Usaha/Dunia Industri/Dunia Kerja.

Namun ironisnya, fenomena yang berkembang yang dialamatkan kepada lembaga pendidikan kejuruan dewasa ini adalah kurang mampunya lembaga pendidikan menyiapkan sumber daya manusia yang dibutuhkan oleh masyarakat, dalam hal ini pasar kerja terutama dunia industri. Ketidakmampuan ini dikandung pengertian tidak adanya kesesuaian kualifikasi antara output pendidikan dengan realitas tuntutan dunia industri yang sangat maju dengan pesatnya.

Untuk mampu mencapai kualifikasi dan kompentensi yang dibutuhkan DUDI, maka Sekolah Menengah Kejuruan perlu merancang kegiatan konkrit yang relevan dengan kebutuhan siswa ketika belajar dan setelah lulus kelak. Berkaitan dengan penyiapan tenaga kerja ini, secara eksplisit disebutkan dalam Peraturan Pemerintah Nomor 29 tahun 1990 pada pasal 29 ayat 2, bahwa: "Untuk mempersiapkan siswa SMK menjadi tenaga kerja, pada SMK dapat didirikan Unit Produksi yang beroperasional secara profesional". Disamping itu, muara lulusan dari pendidikan di SMK pada dasarnya tidak hanya dicetak untuk dapat bekerja secara professional di dunia industri, namun juga bekerja secara mandiri melalui berwirausaha dalam bidangnya.

Hadirnya unit produksi pada SMK dapat memberikan pengalaman kerja nyata (real to work) bagi siswanya agar menguasai kompetensi produktif secara profesional. Di samping itu, siswa juga dipersiapkan untuk menjadi pribadipribadi wirausahawan agar tamatannya tidak hanya menjadi pencari kerja (job seeker) tetapi juga dapat menjadi pencipta lapangan kerja (job creator). Kompetensi kewirausahaan tersebut salah satunya dapat diperoleh melalui pembelajaran di unit produksi/jasa sekolah. Hal ini pun sejalan dengan pernyataan Priseiden RI, bahwa jiwa wirausaha harus dipupuk sejak kecil sehingga pendidikan nasional tidak hanya melahirkan para pencari kerja tetapi pencipta lapangan kerja. (Kominfo Newsroom, 2009: 1)

Pada dasarnya unit produksi merupakan suatu program upaya peningkatan mutu sekolah yang dirancang sebagai wadah menciptakan lulusan yang berjiwa wirausaha dan peningkatan kemampuan serta keterampilan sumberdaya manusia, siswa dan guru, disamping sebagai suatu usaha untuk mengoptimalkan penggunaan fasilitas sekolah yang dapat memberikan nilai tambah bagi sekolah.

Unit produksi sekolah terutama dapat berperan dalam pembekalan keterampilan produksi yang sesuai dengan kebutuhan tenaga kerja pada pasar industri, oleh karena itu pengelolaan unit produksi sekolah memerlukan kemampuan manajerial untuk berinovasi dalam 
pengelolaan sumber daya manusia, sumber daya fasilitas, serta pengelolaan kegiatan belajar mengajar siswa agar unit produksi secara optimal dapat mendukung pelaksanaan program unit produksi. Unit produksi juga merupakan suatu usaha incorporated-intrapreneur atau suatu wadah kewirausahaan sekolah yang mempunyai kewenangan khusus dari pimpinan sekolah kepada pengelola untuk secara demokratis melakukan tugas dan tanggung jawabnya. Karena unit produksi adalah wadah kewirausahaan di sekolah, maka dalam pelaksanaannya harus dikelola untuk dikembangkan dalam suatu wadah usaha.

Agar unit produksi sekolah dapat menjadi sumber pembelajaran dan pendanaan pendidikan maka perlu dikelola secara profesional. Disamping itu akan memberikan keuntungan, seperti dijelaskan pada strategi Dikmenjur 20002005, keuntungannya meliputi: (1) menambah penghasilan SMK yang dapat digunakan untuk meningkatkan kesejahteraan warganya; (2) memperbaiki dan meremajakan fasilitas sekolah; (3) mendekatkan relevansi program kejuruan dengan kebutuhan dunia industri; dan (4) menyiapkan siswa berlatih kerja secara nyata dan bertanggung jawab, karena hasil kerjanya akan dijual di pasaran umum.

Namun kenyataannya kemajuan unit produksi masih lamban, belum tertanamnya wawasan bisnis di SMK, langkanya sumberdaya manusia yang mampu dan sanggup mengelola unit produksi serta kurangnya dukungan dari pihak-pihak pengelola SMK, (Wardiman, 1998: 107). Hambatan lainnya adalah lemahnya manajemen pengeloalaan unit produksi sehingga unit produksi berjalan apa adanya, hanya memenuhi aturan bahwa SMK harus memiliki unit produksi. Padahal secara operasional, penyelenggaraan unit produksi disamping bertujuan untuk mendapatkan keuntungan juga sebagai wadah pembelajaran siswa. Sehingga hal ini menjadi hambatan dalam pelaksanaan pembelajaran melalui unit produksi.

Disamping itu pula keterlibatan siswa dalam penyelenggaraan unit produksi belum terlaksana secara optimal. Kegiatan siswa dalam unit produksi hanya sebatas menangani pekerjaan yang bersifat praktis, belum sampai kepada manajemen pengelolaannya. Hal ini diperkuat oleh Widiarto (1997) menyatakan bahwa peran siswa dalam kegiatan unit produksi masih relatif kecil, sebatas menangani pekerjaan yang bersifat praktis, dan dari segi jumlahnya masih sedikit sekali, yaitu sekitar $2 \%$.

Dari penjelasan tersebut terlihat adanya kesenjangan antara kebijakan dengan operasional penyelenggaraan unit produksi sebagai bagian dari model pembelajaran kewirausahaan di SMK guna menciptakan lulusan yang memiliki sikap berwirausaha dan memiliki kompetensi keahlian. Dari hasil pra survei penelitian yang dilakukan pada tanggal 25 Desember 2010 hingga 30 Desember 2010 di tiga tempat yang menjadi rekomendasi para ahli yaitu SMK Negeri 3 Klaten, SMK Negeri 6 Yogyakarta, dan SMK Negeri 4 Yogyakarta didapatkan bahwa pengelolaan unit produksi sebagai salah satu fasilitas pembelajaran kewirausahaan yang baik adalah SMK Negeri 6 Yogyakarta.

Hasil pra survey di SMK Negeri 6 Yogyakarta menunjukkan bahwa: 1) terdapat unit produksi dalam program studi jasa boga di sekolah tersebut yang dijadikan tempat pengalaman praktis (practical experience) bagi 
siswa; 2) unit produksi sekolah telah mengacu pada standar keahlian yaitu standar keahlian Jasa Boga; 3) unit produksi sekolah telah mengelola sumber daya sekolah untuk menghasilkan barang atau jasa secara rutin yang akan dijual untuk mendapatkan keuntungan financial; 4) melibatkan siswa dalam kegiatan operasionalnya yang dapat menjadi sarana pelatihan nyata (on the job training) bagi siswa maupun staff pengajar; 5) terdapat proses pembelajaran kewirausahaan dalam kegiatan unit produksi yaitu dengan pemberian modal usaha kepada siswa; 6) menjalin kemitraan dengan institusi pasangan dalam mengembangkan unit produksi sekolah.

Untuk itu diperlukan penelitian tentang proses pembelajaran kewirausahaan melalui penyelenggaraan unit produksi di SMK Negeri 6 Yogyakarta yang meliputi: 1) konsepsi guru terhadap pembelajaran kewirausahaan; 2) kompetensi kewirausahaan yang dikembangkan dalam kegiatan unit produksi jasa boga; 3) proses pembelajaran kewirausahaan melalui kegiatan unit produksi jasa boga yang meliputi strategi, pelaksanaan, dan monitoring dan evaluasi pembelajaran.

\section{METODE PENELITIAN}

Penelitian ini menggunakan pendekatan kualitatif dengan jenis penelitian studi kasus (case study). Menurut Robert E. Stake (Denzin \& Lincoln, 2009: 299) studi kasus bukanlah sebuah pilihan metodoligis, namun lebih sebagai pilihan objek yang diteliti. Muhadjir (1996: 38) menjelaskan bahwa penelitian studi kasus didasarkan ketajaman peneliti melihat kecenderungan, pola arah, interaksi banyak faktor dan hal lain yang memacu atau menghambat perubahan. Penelitian ini dilakukan di SMK Negeri 6 Yogyakarta. Pemilihan ini dilatarbelakangi dengan kelengkapan dan kemapanan dalam penyelenggaraan unit produksi sebagai salah satu bentuk pembelajaran. Waktu penelitian ini dilaksanakan pada bulan Desember sampai dengan Maret tahun ajaran 2010/2011.

Subjek penelitian ini adalah penanggung jawab unit produksi, pengelola unit produksi, dan pelaksana unit produksi SMK Negeri 6 Yogyakarta. Sebagai key informan untuk mendapatkan data mengenai proses pembelajaran melalui penyelenggaran unit produksi dan perkembangan kompetensinya adalah kepala SMK Negeri 6 Yogyakarta.

Dalam penelitian ini peneliti mengumpulkan data menggunakan metode wawancara, observasi, dan dokumentasi. analisis data yang digunakan dalam penelitian ini adalah Analysis Interactive Model dari Miles dan Huberman (1985: 23) yang membagi kegiatan analisis menjadi beberapa bagian yaitu: pengumpulan data, pengelompokan menurut variabel, reduksi data, penyajian data, memisahkan outlier data, dan penarikan kesimpulan atau verifikasi data.

\section{HASIL PENELITIAN}

\section{Konsepsi Guru terhadap Pembelajaran Kewirausahaan}

Dalam pendidikan di SMK tidak dapat melepaskan diri dari pendidikan kewirausahaan, karena salah satu lulusannya selain diarahkan untuk bekerja dalam dunia industri juga disiapkan untuk dapat menciptakan lapangan kerja baru di bidangnya melalui berwirausaha. Untuk membentuk siswa menjadi seorang wirausaha tidaklah cukup hanya berbekal bakat 
yang dimiliki oleh siswa, namun juga siswa harus memiliki pengetahuan mengenai segala aspek usaha yang akan ditekuninya. Siswa dapat mengembangkan bakatnya melalui pendidikan di sekolahnya. Hal ini sekaligus membantah anggapan bahwa kewirausahaan merupakan bakat bawaan sejak lahir, sehingga tidak dapat dipelajari dan diajarkan.

Oleh karenanya model dan sistem pendidikan di SMK harus menunjang untuk menciptakan tenaga-tenaga wirausaha baru melalui pendidikan kewirausahaan. Pendidikan kewirausahaan diharapkan mampu mengasah kemampuan nalar dan bakat kewirausahaan siswa agar bisa membuka lapangan pekerjaan baru.

Kondisi ini dapat dicapai bila pendidikan kewirausahaan yang diberikan kepada siswa bukanlah sekedar pengajaran teori semata, namun juga aplikasi langsung yaitu dengan cara melibatkan siswa langsung dalam kegiatan nyata berwirausaha. Kesadaran akan pentingnya pendidikan kewirausahaan ini telah disadari oleh para pendidik di SMK Negeri 6 Yogyakarta. Hal ini tercermin dalam proses pembelajaran yang telah menyelenggarakan kegiatan unit produksi sebagai salah satu fasilitas belajar siswa dalam melatih keterampilan produktif dan keterampilan berwirausaha dengan aplikasi langsung. Menurut Singh (1998: 48) bahwa penyelenggaraan unit usaha sekolah (unit produksi) efektif dalam mengembangkan keterampilan berwirausaha untuk memenuhi kebutuhan masyarakat dan dalam pengembangan barang atau jasa yang disesuaikan dengan kebutuhan masyarakat.

Disamping itu, hadirnya kebijakan tentang implementasi pendidikan karakter pada setiap jenjang pendidikan termasuk SMK telah mendukung dalam penanaman nilai-nilai kewirausahaan bagi siswa. Karena nilai-nilai kewirausahaan merupakan bagian dari nilai-nilai dasar pendidikan karakter yaitu seperti bertanggungjawab, disiplin, kerja keras, kreatif, dan mandiri. Nilai-nilai tersebut dapat diintegrasikan dalam pembelajaran pada setiap mata pelajaran. Sehingga penanaman nilai-nilai kewirausahaan dapat diaplikasikan secara luas, tidak hanya diterapkan pada mata pelajaran kewirausahaan saja tapi juga dapat diintegrasikan dalam mata pelajaran lain baik kelompok mata pelajaran normatif, adaptif, maupun produktif.

Realisasinya, sekolah telah mengupayakan untuk menyusun kurikulum dengan memasukkan nilai-nilai kewirausahaan kedalam pendidikan karakter bangsa. Nilai-nilai tersebut telah termuat di dalam kurikulum dalam bentuk hidden curriculum. Namun sejauh ini, upaya tersebut belum mampu membentuk siswa untuk menjadi seorang wirausaha, termasuk mata pelajaran teori kewirausahaan. Oleh karenanya diperlukan kegiatan belajar kewirausahaan yang riil atau nyata, yaitu dengan melibatkan siswa dalam kegiatan unit produksi sekolah. Penanaman nilai-nilai kewirausahaan dan pengetahuan yang didapatkan siswa dalam mata pelajaran normatif, adaptif dan produktif akan diaplikasikan secara nyata oleh siswa dalam kegiatan belajar di unit produksi. Sehingga dapat dikatakan pembelajaran unit produksi merupakan muara pembelajaran kewirausahaan bagi siswa. Dengan demikian, pembelajaran nilai-nilai kewirausahaan tidak hanya dilakukan pada tataran kognitif, tetapi menyentuh pada internalisasi, dan pengamalan nyata dalam 
bentuk keterlibatan siswa untuk mengelola usaha di unit produksi.

Dalam pembelajarannya, unit produksi memiliki tujuan jangka pendek (short term) dan jangka panjang (long term). Tujuan jangka pendek dari pembelajaran unit produksi yaitu sebagai sumber dana sekolah yang didapatkan dari keuntungan produksi, keuntungan tersebut digunakan untuk biaya operasional sekolah. Sedangkan tujuan jangka panjangnya yaitu untuk membentuk siswa menjadi self-employee, yaitu pemberi kerja bagi dirinya dan orang lain dengan berwirausaha.

Hal ini terlihat bahwa meskipun unit produksi merupakan pembelajaran berbasis bisnis atau perolehan keuntungan namun tetap mengedepankan nilai edukasinya, yaitu proses pembelajaran bagi siswa dalam melatih keterampilan produktif dan keterampilan berwirausaha.

\section{Kompetensi Kewirausahaan yang Dikembangkan}

Kompetensi kewirausahaan yang akan dikembangkan akan dijadikan sebagai landasan melakukan proses pembelajaran dan penilaian siswa. Namun sayangnya, saat ini kompetensi kewirausahaan yang dikembangkan dalam pembelajaran di unit produksi belum tertuang dan bahkan belum terkonsep dalam perencanaan pembelajaran di unit produksi. Meskipun kompetensi tersebut belum terkonsep namun proses pembelajaran kewirausahaan sudah berjalan yaitu dengan adanya penanaman nilainilai kewirausahaan yang dilakukan oleh guru kepada peserta didik yang bermuara pada pengembangan kompetensi kewirausahaan.

Dalam hal ini peneliti telah melakukan identifikasi terhadap kompetensi kewirausahaan yang dikembangkan oleh sekolah dalam pembelajaran di unit produksi, identifikasi tersebut dengan cara wawancara, observasi, dan dokumentasi selama proses pengambilan data di lapangan. Mengacu pada definisi kompetensi yang diungkapkan oleh Martinis (2005: 127) bahwa kompetensi adalah kemampuan dasar yang dapat dilakukan oleh para siswa pada tahap pengetahuan, keterampilan, dan sikap. Maka kompetensi kewirausahaan tersebut dijabarkan kedalam tiga kelompok besar yaitu pengetahuan, sikap, dan keterampilan seorang wirausaha.

Pertama; pengetahuan kewirausahaan. Dari hasil penelitian, dalam proses pembelajaran di unit produksi SMK Negeri 6 Yogyakarta sebagian besar guru menyadari bahwa pengetahuan yang dikembangkan hanya bersifat pengetahuan teknis. Kondisi ini serupa dengan pernyataan Gibb (Fayolle, 2007: 74) bahwa dalam pendidikan formal sebagian besar pembelajarannya hanya memusatkan pada proses transfer explicit knowledge. Sedangkan pengetahuan yang bersifat tacit knowledge belum banyak disadari oleh guru, padahal pengetahuan ini sangat penrting dalam membentuk karakter seorang wirausaha. Namun demikian pengetahuan yang bersifat tacit knowledge sudah diajarkan atau dikembangkan oleh guru pada pembelajaraan kewirausahaan melalui kegiatan unit produksi, baik disadari maupun tidak disadari dalam proses penyampaiannya. Misalnya ketika guru memberikan tugas kepada siswa dalam mengelola usaha kelompok dengan pemberian modal untuk dikembangkan, maka sebenarnya saat itu guru telah mengajarkan secara tidak langsung kepada siswa bahwa uang dipandang sebagai suatu sumber daya, bukan tujuan akhir 
usaha. Uang atau laba yang diperoleh oleh siswa akan dikelola secara proaktif dan dijadikan sumber daya dalam mengembangkan usahanya secara terus menerus.

Adapun pengetahuan kewirausahaan yang dikembangkan meliputi self knowledge dan practical knowledge. Self knowledge merupakan pengetahuan yang bersifat tacit knowledge yang berkaitan dengan pengetahuan tentang jenis usaha yang akan dijalankan dan pengetahuan dasar tentang kewirausahaan. Sedangkan practical knowledge merupakan pengetahuan yang bersifat explicit knowledge yang berkaitan dengan pengetahuan yang bersifat praktis seperti pengetahuan tentang teknik memasak dan memproduksi, quality control product, pembukuan, dan pemasaran.

Kedua; sikap kewirausahaan. Sikap kewirausahaan yang dikembangkan meliputi etos kerja, kemandirian, disiplin, dan kreatif dan inovatif. Penanaman nilai-nilai tersebut sangatlah penting dan sudah mulai ditanamkan kepada siswa dalam pembelajaran kewirausahaan melalui kegiatan unit produksi. Hal ini dianggap penting karena secara umum sikap kewirausahaan sangat dibutuhkan dalam mempertahankan kelangsungan hidup manusia, terlebih dalam menjalankan usaha di bidang tata boga..

Ketiga; keterampilan kewirausahaan. Berbekal pengetahuan dan sikap kewirausahaan saja tidaklah cukup jika tidak dilengkapi dengan bekal keterampilan. Beberapa keterampilan kewirausahaan yang dikembangkan dalam pembelajaran kewirausahaan melalui kegiatan Unit Produksi Jasa Boga SMK Negeri 6 Yogyakarta diantaranya adalah technical skill (keterampilan teknis), human relations skill (keterampilan berelasi), conceptual skill (keterampilan konseptual), decision making skill (keterampilan pengambilan keputusan), time management skill (keterampilan mengatur waktu), dan leadership skill (keterampilan kepemimpinan). Dalam hal ini keterampilan produktif atau keterampilan kejuruan sesuai dengan kompetensi keahlian sudah termasuk dalam technical skill. Sedangkan yang lainnya merupakan keterampilan pendukung.

\section{Proses Pembelajaran Kewirausahaan di Unit Produksi}

Adanya asumsi bahwa kewirausahaan tidak dapat dipelajari dan diajarkan karena hanya dapat dilakukan melalui pengalaman langsung dan sudah merupakan bakat yang dibawa sejak lahir adalah salah besar. Karena pada hakekakatnya kewirausahaan merupakan disiplin ilmu yang dapat dipelajari dan diajarkan. Seperti halnya pernyataan menurut Suryana (2009:10) bahwa kewirausahaan merupakan disiplin ilmu yang mempelajari tentang nilai, kemampuan, dan perilaku seseorang dalam menghadapi tantangan hidup untuk memperoleh peluang dengan berbagai resiko yang mungkin dihadapinya.

Oleh karenanya unsur-unsur pembelajarannya harus dirancang sebaikbaiknya agar benar-benar dapat menciptakan seorang wirausaha dalam bidangnya. Disamping itu, proses pembelajaran dalam pendidikan kewirausahaan harus diarahkan kepada pemanfaatan nyata terhadap pengetahuan dan kemampuan untuk bekal hidup peserta didik di tengah-tengah kehidupan bermasyarakat. Hal ini menjadi tantangan bagi dunia pendidikan untuk dapat merancang desain proses pembelajaran sebaik dengan pengalaman nyata (hands-on 
experiences), Hjorth (Fayolle, 2007: 50). Dan salah satu cara yang dapat dilakukan yaitu dengan cara melibatkan siswa langsung ke dalam kegiatan nyata dalam berwirausaha (by doing) atau dengan cara magang (apprenticeship), Itkonen (Stenström \& Tynjälä, 2009: 160).

Sejauh ini dalam proses pembelajaran kewirausahaan, internalisasi atau penanaman nilai-nilai kewirausahaan kepada siswa dalam kegiatan unit produksi sudah dilakukan oleh para guru, namun masih belum banyak disadari sepenuhnya oleh para guru bahwa apa yang dilakukannya merupakan bagian dari proses pembelajaran kewirausahaan. Sebenarnya munculnya ketidaksadaran guru tersebut dipicu oleh ketidaktahuan guru terhadap konsep pembelajaran kewirausahaan. Dalam pembelajarannya, seorang guru lebih terfokus pada pencapaian kemampuan aspek kognitif dan psikomotorik kewirausahaan siswa seperti pengetahuan dan keterampilan produktif atau kejuruan di bidang tata boga dan melupakan pencapaian kemampuan aspek sikap (afektif). Padahal penanaman sikap kewirausahaan tersebut adalah hal yang terpenting untuk membentuk karakter seorang wirausaha. Mana mungkin seseorang dapat mengelola sebuah usaha dengan berbekal kemampuan pengetahuan dan keterampilan saja tanpa memiliki kemampuan dalam aspek sikap seperti kreatif dan inovatif, mandiri, berani mengambil resiko, dan yang lainnya.

Target pencapaian kompetensi kewirausahaan siswa yang belum terkonsep dalam kegiatan unit produksi dan kurangnya kesadaran guru dalam proses pembelajaran kewirausahaan melalui kegiatan unit produksi dikarenakan kegiatan unit produksi merupakan Kegiatan Belajar Mengajar (KBM) di luar kelas yang belum merumuskan tujuan instruksional dalam pembelajarannya dan juga program ini terlepas dari kegiatan intrakurikuler. Hal inilah yang menyebabkan pembelajaran kewirausahaan melalui kegiatan unit produksi belum terkonsep dengan matang.

\section{Strategi Pembelajaran}

Meskipun kegiatan unit produksi terlepas dari Kegiatan Belajar Mengajar di kelas dan belum ada tujuan instruksional yang jelas dalam pembelajarannya namun sudah diterapkan beberapa strategi dalam proses pembelajarannya. Beberapa upaya merumuskan strategi pembelajaran tersebut dapat terlihat dari upaya yang telah dilakukan oleh guru dalam pembelajaran di unit produksi yaitu:

Pertama; menentukan sasaran atau tujuan pembelajaran. Sasaran atau tujuan dari pembelajaran kewirausahaan melalui kegiatan unit produksi SMK Negeri 6 Yogyakarta yaitu untuk membentuk siswa menjadi seorang entrepreneur dalam bidangnya. Salah satu upaya yang dilakukan yaitu dengan melibatkan siswa dalam pengelolaan usaha secara langsung di unit produksi sekolah. Dan siswa sudah sejak dini dikenalkan dengan berwirausaha, sejak kelas satu (X) mereka sudah dilibatkan dalam kegiatan unit produksi sekolah. Meskipun keterlibatan mereka hanya terbatas pada pekerjaan teknis yang ringan, seperti mencuci piring, mengepel, menyiapkan bahan, dan inventaris bahan dan alat.

Kedua; menentukan pendekatan pembelajaran. Pendekatan pembelajaran dalam kegiatan unit produksi yang digunakan adalah pendekatan Production Based Training (PBT), 
pendekatan ini menekankan pada proses pembelajaran keterampilan yang dirancang dan dilaksanakan berdasarkan prosedur kerja yang sesungguhnya untuk menghasilkan barang atau jasa yang sesuai dengan tuntutan pasar atau konsumen. Dalam hal ini siswa diarahkan agar dapat menghasilkan barang atau jasa di bidang boga. Produk yang dihasilkan dari kegiatan unit produksi ini berupa produk makanan dan minuman (food and beverage product), sedangkan jasa yang ditawarkan berupa jasa catering dan jasa pelatihan (training course) seperti pelatihan table manner.

Ketiga; menentukan model pembelajaran. Secara garis besar implementasi pembelajaran kewirausahaan di SMK Negeri 6 Yogyakarta dibagi menjadi 3 bagian, yaitu; 1) Kewirausahaan, 2) Pengelolaan Usaha, 3) dan Unit Produksi. Model pembelajaran di unit produksi dibagi menjadi 3 (tiga) macam, yaitu: 1) Inside Production; 2) Outside Production; 3) Mobile Canteen. Model pembelajaran inside production diimplementasikan dalam 4 kegiatan unit produksi, yaitu: 1) Production Kitchen (PK); 2) Sanggar pattiseri; 3) Kantin kenari 4; dan 4) Kantin siswa.

\section{Pelaksanaan Pembelajaran}

Pelaksanaan pembelajaran kewirausahaan yang dilakukan oleh sekolah melalui kegiatan unit produksi jasa boga bervariasi, hal ini dilakukan agar proses pembelajaran kewirausahaan tidak monoton dan membosankan bagi siswa. Model pembelajaran yang digunakan yaitu dengan melibatkan siswa langsung dalam pengalaman belajar nyata yaitu mengelola sebuah usaha di bidangnya. Hal ini sangat efektif dalam mengarahkan siswa untuk mencapai kompetensi yang dikembangkan.
Seperti halnya pernyataan Carrier (Fayolle, 2007: 150) bahwa pendekatan pembelajaran berdasarkan pengalaman dapat mendukung untuk memperoleh keterampilan, kompetensi, dan sikap kewirausahaan, disamping itu pula dapat memperkuat integrasi perolehan kompetensi lebih dari sekedar teori dan pengetahuan teknis. Dalam konteks tersebut siswa dilibatkan langsung dalam 4 kegiatan yaitu mengetahui (knowing), berpikir (thinking), melakukan (doing), dan berpartisipasi (participating). Adapun beberapa model pembelajaran yang diterapkan dalam pembelajaran di unit produksi SMK Negeri 6 Yogyakarta yaitu: 1) Model pembelajaran inside production; 2) Model pembelajaran outside production; 3) Model pembelajaran mobile canteen.

Pertama; model pembelajaran inside production. Model pembelajaran inside production ini menerapkan agar siswa memproduksi produk di unit produksi sekolah, dengan menggunakan fasilitas sekolah. Model pembelajaran ini diterapkan pada 4 unit produksi jasa boga, yaitu di Production Kitchen (PK), Sanggar Pattiseri, Kantin Kenari 4, dan Kantin Siswa.

Kedua; model pembelajaran outside production. Model pembelajaran ini mengarahkan siswa untuk dapat merintis usaha sendiri maupun kelompok dengan membentuk usaha kelompok, prinsip kerja yang digunakan adalah berproduksi di luar sekolah, dengan kata lain siswa membuat produk dengan menggunakan fasilitas pribadi yaitu di rumah masing-masing. Dalam hal ini posisi siswa adalah sebagai pengelola dan pemilik usaha sekaligus pelaksana usaha tersebut. Model 
pembelajaran ini sangat tepat untuk membentuk karakter wirausaha, dan bahkan sebagian besar kompetensi yang dikembangkan termuat dalam proses pembelajaran dengan menggunakan model pembelajaran outside production. Dengan model pembelajaran ini siswa diajarkan dalam merintis sebuah usaha kelompok, mulai dari menyusun ide usaha hingga pada pengembangannya. Oleh karenanya sebagai prasyarat untuk mengikuti pembelajaran ini siswa harus memiliki beberapa kompetensi dasar, dimana kompetensi dasar tersebut sudah didapatkan oleh siswa pada saat kelas $\mathrm{X}$ yaitu pengetahuan kewirausahaan, keterampilan mengolah makanan, dan keterampilan menyajikan makanan.

Ketiga; model pembelajaran mobile canteen. Model pembelajaran kewirausahaan ini menerapkan konsep penjualan dengan menggunakan counter/stand non permanen. Sejauh ini pelaksanaan model pembelajaran tersebut baru terimplementasikan di lingkungan sekolah, padahal Kepala SMK Negeri 6 Yogyakarta mengharapkan agar model pembelajaran ini dapat berekspansi ke luar lingkungan sekolah.

\section{Monitoring dan Evaluasi}

Pelaksanaan monitoring dan evaluasi harus memberikan manfaat pedagogis, yaitu dalam mendukung sistem pembelajaran (Singh, 1998: 45). Dari hasil monitoring dan evaluasi dapat dijadikan acuan dalam pelaksanaan pembelajaran berikutnya, hal ini dilakukan agar dapat memperbaiki dan meningkatkan kualitas pembelajarannya.

Dalam pelaksanaan monitoring kegiatan unit produksi dilakukan oleh guru pembimbing yaitu dari guru produktif. Setiap unit produksi inside production dimonitoring oleh dua orang guru, sedangkan unit produksi yang lainnya dimonitoring oleh satu orang guru. Peran guru sebagai tim monitoring selain mengontrol jalannya operasional kegiatan unit produksi juga memantau kemajuan belajar siswa yang terlibat dalam kegiatan unit produksi. Disamping itu juga guru sebagai quality control product atas hasil produksi siswa, hasil produksi siswa akan mendapat pengontrolan agar tetap memiliki kualitas produk yang baik.

Berdasarkan dari hasil data penelitian yang diperoleh, pelaksanaan monitoring terhadap kemajuan belajar siswa dapat dilihat dari dua aspek yaitu monitoring terhadap kinerja siswa (performance monitoring) dan monitoring terhadap hasil produksi siswa (product monitoring). Menurut Salim Peter (Husaini Usman, 2009: 488) bahwa kinerja digunakan apabila seseorang menjalankan tugas atau proses dengan terampil sesuai dengan prosedur dan ketentuan yang ada. Sedangkan produknya dapat berupa layanan jasa ataupun barang. Sehingga antara kinerja dan produk memiliki keterkaitan satu sama lain, kinerja yang baik dari siswa akan dapat menciptakan produk yang baik pula.

Pelaksanaan evaluasi belajar masih belum dilakukan dengan maksimal, terlebih evaluasi terhadap pencapaian kompetensi kewirausahaan siswa. Hal ini karena guru masih menganggap bahwa kegiatan unit produksi merupakan kegiatan belajar siswa yang terlepas dari Kegaiatan Belajar Menagajar (KBM) di kelas dan belum ada tujuan instruksionalnya, sehingga tidak diperlukan perangkat belajar yang lengkap seperti halnya kegiatan pembelajaran di kelas. Meskipun demikian, sudah ada upaya-upaya yang dilakukan oleh guru untuk mengukur 
kemajuan belajar siswa yaitu dilakukan dengan mengukur perolehan keuntungan dari hasil penjualan produk. Sehingga pengukuran kemajuan belajar siswa masih berorientasi pada perolehan keuntungan atau disebut juga profit based evaluation dan belum mencapai pada tataran pencapaian kompetensi kewirausahaan siswa.

\section{KESIMPULAN}

\section{Konsepsi Guru Tentang Pembelajaran Kewirausahaan}

Dalam membentuk siswa menjadi seorang wirausaha yang mampu menciptakan lapangan kerja baru di bidangnya tidaklah cukup hanya berbekal bakat yang dimiliki oleh siswa, namun juga siswa harus memiliki pengetahuan mengenai segala aspek usaha yang akan ditekuninya. Untuk mewujudkan hal tersebut diperlukan pembelajaran kewirausahaan berdasarkan pengalaman nyata yaitu dengan cara melibatkan siswa langsung ke dalam kegiatan nyata berwirausaha (hands-on experience), salah satunya yaitu melalui pembelajaran kewirausahaan di unit produksi.

\section{Kompetensi Kewirausahaan Yang Dikembangkan}

$$
\text { Kompetensi kewirausahaan yang }
$$

dikembangkan dalam pembelajaran di unit produksi yaitu 1) pengetahuan kewirausahaan, meliputi: self knowledge dan practical knowledge; 2) sikap kewirausahaan, meliputi: etos kerja, kemandirian, disiplin, kreatif dan inovatif; 3) keterampilan kewirausahaan, meliputi: keterampilan teknis (technical skill), keterampilan berelasi (human relations skill), keterampilan konseptual (conceptual skill), keterampilan pengambilan keputusan (decision making skill), keterampilan mengelola waktu (time management skill), dan keterampilan kepemimpinan (leadership skill).

\section{Proses Pembelajaran Kewirausahaan di Unit Produksi}

a. Penyusunan strategi pembelajaran dalam kegiatan unit produksi belum dilakukan, hal ini dikarenakan belum adanya tujuan instruksional dalam kegiatan tersebut. Disamping itu, paradigma yang berkembang dikalangan guru-guru bahwa kegiatan unit produksi merupakan kegiatan pembelajaran yang terlepas dari kegiatan intrakurikuler sehingga tidak diperlukan desain instruksional yang baku dalam pembelajarannya seperti kegiatan pembelajaran di kelas.

b. Meskipun tujuan instruksional belum terumuskan, namun guru-guru sudah melakukan internalisasi nilai-nilai kewirausahaan kepada siswa dalam pembelajaran kewirausahaan melalui unit produksi, namun belum disadari secara langsung oleh guru bahwa sebetulnya yang dilakukan guru tersebut merupakan bagian dari penanaman nilai atau kompetensi kewirausahaan. Upaya penanaman nilai-nilai tersebut sudah dilakukan melalui pelaksanaan tiga model pembelajaran kewirausahaan di unit produksi SMK Negeri 6 Yogyakarta yaitu 1) inside production, 2) outside production, dan 3) mobile canteen.

c. Pelaksanaan monitoring pembelajaran dilakukan dengan dua cara yaitu: 1) performance monitoring); dan 2) product monitoring. Sedangkan upaya evaluasi yang telah dilakukan terhadap kemajuan belajar siswa dalam mengikuti kegiatan pembelajaran di unit produksi yaitu dengan 
cara mengukur perolehan keuntungan dari hasil penjualan produk (profit based evaluation).

\section{SARAN}

1. Diharapkan kepada Dinas Pendidikan Nasional Propinsi DIY dan Dinas Pendidikan dan Pengajaran Kota Yogyakarta, agar dapat memberikan pedoman pelaksanaan dalam pengelolaan pembelajaran kewirausahaan melalui penyelenggaraan unit produksi pada SMK dan sekaligus dapat memberikan bantuan modal usaha bagi SMK.

2. Diharapkan kepada pihak SMK Negeri 6 Yogyakarta untuk dapat merumuskan kembali desain instruksional dalam pembelajaran kewirausahaan melalui kegiatan unit produksi agar tujuan pembelajaran dapat tercapai dengan baik.

3. Diharapkan kepada pihak SMK Negeri 6 Yogyakarta untuk dapat mensinkronkan antara mata pelajaran teori kewirausahaan dengan pembelajaran di unit produksi agar proses pembelajarannya memiliki keterkaitan satu sama lain.

4. Diharapkan kepada pihak SMK Negeri 6 Yogyakarta agar terus melakukan terobosan pembelajaran kewirausahaan dengan mengkomunikasikan ke berbagai pihak seperti Dinas Pendidikan Nasional Propinsi DIY dan Dinas Pendidikan dan Pengajaran Kota Yogyakarta, pengusaha, dermawan dan lain-lain agar unit produksi dapat menjadi sumber pembelajaran kewirausahaan yang baik.

5. Diharapkan kepada pihak SMK Negeri 6 Yogyakarta untuk tetap membangun komunikasi dengan masyarakat dan wali murid agar masyarakat dan wali murid lebih meningkatkan partisipasinya dalam menerapkan dan mengembangkan pembelajaran di sekolah.

\section{UCAPAN TERIMA KASIH}

Penelitian ini merupakan penelitian Hibah Pasca yang didanai oleh DP3M Dirjen Ditjen Dikti Kementerian Pendidikan Nasional. Oleh sebab itu peneliti mengucapkan terimasih kepada DP3M Dirjen Ditjen Dikti yang telah memberikan dana dan kesempatan kepada peneliti untuk melakukan penelitian di SMK Negeri 6 Yogyakarta. Ucapan terimakasih ditujukan kepada Prof. Sukamto M.Sc, Ph.D. selaku Ketua Peneliti Hibah Pasca dan Prof. Pardjono, M.Sc., Ph.D yang telah membimbing dalam proses penelitian ini.

\section{DAFTAR PUSTAKA}

Denzin, Norman. K., \& Lincoln, Yvonna S. (2009). Handbook of qualitative research. California: Sage Publication.

Depdiknas. (1989). Undang-undang RI Sistem Pendidikan Nasional Nomor 2, tahun 1989, tentang Sistem Pendidikan Nasional.

Depdiknas. (1990). Peraturan Pemerintah RI Nomor 29, Tahun 1990, tentang Pendidikan Menengah.

Fayolle, Alain. (Eds). (2007). Handbook of research in entrepreneurship education, volume 1. UK: Edward Elgar Publishing.

Husaini Usman. (2009). Manajemen: teori, praktek, dan riset pendidikan. Jakarta: Bumi Aksara.

Kominfo Newsroom. (2009). SBY: guru dan dosen harus kembangkan semangat wirausaha. Diambil pada tanggal 20 September 2010, dari http://www.endonesia.com/mod.php?mod $=$ publisher\&op=viewarticle \&cid=40\&arti $\underline{\mathrm{d}=4571}$ 
Martinis Yamin. (2005). Strategi pembelajaran berbasis kompetensi. ciputat: gaung persada press.

Miles, M.B., \& Huberman, M.A. (1994). Qualitative data analysis: an expanded sourcebook $\left(2^{\text {rd }} e d\right)$. London: Sage Publication.

Noeng Muhadjir. (1996). Metodologi penelitian kualitatif. Yogyakarta: Rake Sarasin.

Stenström, M.L., Tynjälä, P. (2009). Towards Integration of work and learning: strategies for connectivity and transformation. Finland: Springer.
Singh, Madhu. (1998). School enterprises: combining vocational learning with production. Germany: UNESCO.

Suryana. (2009). Kewirausahaan: pedoman praktis, kiat dan proses menuju sukses. Jakarta: Salemba Empat.

Wardiman Djojonegoro. (1998). Pengembangan sumberdaya manusia melalui SMK. Jakarta: PT.Jayakarta Agung Offset.

UNDP. (2009). Human development report. Diambil pada tanggal 2 Juli 2010, dari http://hdr.undp.org/en/statistics/data/. 